\title{
4.4 Different phenotype of anaemia in systemic juvenile idiopathic arthritis (s-JIA) compared to anaemia in other subtypes of JIA $\mathrm{CH}$ Hinze, N Fall, MG Barnes, S Croswell, K Jennings, S Thornton, RA Colbert, DN Glass and AA Grom*
}

Address: Cincinnati Children's Hospital Medical Center, Cincinnati, OH, USA

* Corresponding author

from $15^{\text {th }}$ Paediatric Rheumatology European Society (PreS) Congress

London, UK. 14-17 September 2008

Published: 15 September 2008

Pediatric Rheumatology 2008, 6(SuppI I):S8 doi:I0.I I86/I546-0096-6-SI-S8

This abstract is available from: http://www.ped-rheum.com/content/6/SI/S8

(c) 2008 Hinze et al; licensee BioMed Central Ltd.

\section{Background}

In previous studies of PBMC gene expression in s-JIA we noted a strong erythropoiesis signature in patients with severe anaemia, correlating with an expansion of CD34+ progenitor cells [1]. Therefore, the origin of anaemia in sJIA may be different from anaemia of chronic inflammation. We examined CD34+ progenitor cells and PBMC gene expression in patients with s-JIA and other types of JIA.

\section{Methods}

187 patients with JIA (21 s-JIA and 166 other subtypes) prior to DMARD treatment were studied. PBMCs were isolated using Ficoll gradient centrifugation and analyzed by flow cytometry after CD34 staining. Gene expression analysis was performed on Affymetrix HG U133 plus 2.0 arrays.

\section{Results}

Patients with s-JIA and anaemia had a significant elevation of CD34+ cells compared to patients with other JIA subtypes and anaemia (Table 1). Comparing PBMC gene expression in patients with s-JIA and anaemia and other JIA subtypes and anaemia revealed 671 differentially expressed probes (T-test). Unsupervised hierarchical clustering revealed homogeneous clustering of the s-JIA group. Strongly divergent gene clusters were identified with overexpression of erythropoiesis-related genes in patients with s-JIA.

\section{Conclusion}

Patients with s-JIA and anaemia have an increased output or survival of hematopoietic progenitor cells and a specific erythropoiesis signature. This contradicts the paradigm that anaemia in S-JIA is caused by decreased erythrocyte production due to chronic inflammation. In addition, we recently showed that many patients with s-JIA have fea-

Table I:

\begin{tabular}{llll}
\hline Disease Category & N (flow data available) & Hb in g/dL & CD34+ (\% of PBMC) \\
\hline I. S-JIA $(\mathrm{Hb}<I I \mathrm{~g} / \mathrm{dL})$ & $18(5)$ & $9.4 \pm 1.0^{*}$ & $0.20 \pm 0.12^{*}$ \\
II. Other JIA $(\mathrm{Hb}<\mathrm{II}$ g/dL) & $21(8)$ & $10.5 \pm 0.4^{*}$ & $0.08 \pm 0.03^{*}$ \\
III. S-JIA (Hb $>I I \mathrm{~g} / \mathrm{dL})$ & $3(3)$ & $11.9 \pm 1.0^{*}$ & $0.09 \pm 0.07^{*}$ \\
IV. Other JIA (Hb $>\mathrm{II}$ g/dL) & $145(82)$ & $12.7 \pm 1.0^{*}$ & $0.08 \pm 0.05^{*}$ \\
P value (ANOVA) & & & $1.65 \times 10^{-6}$ \\
\hline
\end{tabular}

*Values are represented as mean \pm standard deviation. Comparison of CD34+ count via $T$ test: I vs. II: $p=0.008, I$ vs. III.: $p=0.19, I$ vs. IV: $p=$ 0.00000 I, II vs. III.: $\mathrm{p}=0.65$, II vs. IV: $\mathrm{p}=0.93$, III vs. IV: 0.74 ). 
tures of subclinical macrophage activation syndrome (MAS) [2]. We hypothesize that anaemia in s-JIA may be due to hemophagocytosis and subclinical MAS.

\section{References}

I. Fall N, Barnes M, Thornton S, Luyrink L, Olson J, llowite NT, Gottlieb BS, Griffin , Sherry DD, Thompson S, et al.: Gene expression profiling of peripheral blood from patients with untreated newonset systemic juvenile idiopathic arthritis reveals molecular heterogeneity that may predict macrophage activation syndrome. Arthritis Rheum 2007, 56:3793-3804.

2. Bleesing J, Prada A, Siegel DM, Villanueva J, Olson J, llowite NT, Brunner HI, Griffin T, Graham TB, Sherry DD, et al:: The diagnostic significance of soluble CDI63 and soluble interleukin-2 receptor alpha-chain in macrophage activation syndrome and untreated new-onset systemic juvenile idiopathic arthritis. Arthritis Rheum 2007, 56:965-97I.

Publish with Biomed Central and every scientist can read your work free of charge

"BioMed Central will be the most significant development for disseminating the results of biomedical research in our lifetime. "

Sir Paul Nurse, Cancer Research UK

Your research papers will be:

- available free of charge to the entire biomedical community

- peer reviewed and published immediately upon acceptance

- cited in PubMed and archived on PubMed Central

- yours - you keep the copyright

Submit your manuscript here:

http://www.biomedcentral.com/info/publishing_adv.asp 